\title{
Narration and Experience: Looking at an Education based on "Poor" Pedagogy" - an Analysis based on a Learning-to-Write Situation
}

\author{
Narração e Experiência: olhares para uma educação \\ "aquém" da pedagogia - um enfoque a partir de uma \\ situação de aprendizado da escrita
}

\author{
César Donizetti Pereira LEITE
}

\begin{abstract}
With an approach that designates the classroom as its central reference point and a concrete classroom situation as its starting point, this paper attempts to reflect a perspective that may suggest a teaching practice that leads to poor pedagogy. To achieve this, this paper will work on inverting the logic we frequently employ when thinking about education and school. From this perspective, some axes become central: (1) to produce a view about the idea of knowledge and learning, (2) an awareness of a certain notion of "to teach" and finally (3) starting from a focus on the type of childhood that creates a necessity of "infantilizing" pedagogy, or in other words, we must aim towards a "poor" pedagogy. I will address this through a study carried out with children in the initial stages of their education and literacy learning.
\end{abstract}

Index Terms: teaching, school, childhood, language

\section{RESUMO}

A partir de um enfoque que tem a sala de aula como referência central e tendo como ponto de partida uma situação concreta de sala de aula, este texto procura refletir uma perspectiva que possa sugerir uma prática docente que caminhe para uma pedagogia "aquém da pedagogia". Para isso trabalhará com uma noção de inversão de lógica no modo frequente que pensamos a educação e que olhamos a escola. Nesta perspectiva, alguns eixos se tornam centrais, (1) o primeiro é produzir um olhar sobre a ideia de

\footnotetext{
${ }^{1}$ The concept of "poor" pedagogy will be developed in this paper, but it is meant to represent a form of pedagogy that contrasts with the current "technical" pedagogy that dominates the educational landscape. "Poor" pedagogy is more concerned with education rather than instruction. It is a form of pedagogy that predates current "technical" pedagogy.
} 
conhecimento e de aprender (2) o segundo de uma noção de uma certa noção do "ensinar" e finalmente o terceiro (3) a partir de um enfoque sobre a infância que cria uma necessidade de "infantilização" da pedagogia, ou seja, devemos caminhar para uma pedagogia que vá "aquém" da pedagogia. Trabalharei isto a partir de um estudo realizado com crianças em processo inicial de escolarização/alfabetização.

Palavras-chave: ensino, escola, infância, linguagem.

\section{Introduction}

Learn, recognize, build, know. Teach, form, inform, deform, transmit. Over the last several years, there have been various ways of talking about the processes that occur in the educational practices of our society, particularly those in school. The discussions are colored by methodological, pedagogical and psychological reflections, as well as the profound cultural and social transformations through which we have lived. They bypass the feeling of unease that echoes through school halls and sticks to teachers' frustrations.

What we know is that marked by profound comings and goings, the debates about what to do in and for education have effectively contributed little to progress. I do not believe that these "doings" are merely a heap of articles, studies and public policies distant and distanced from educational reality. What I examine here is the fact that this reality has been constructed on a daily basis in an extremely complex and multifaceted manner.

This breaking apart, this shard had often demanded of the teacher much more than he believes himself capable of giving (I do not mean that the teacher is incapable; I merely indicate that from this perspective, "incapability" is a sentiment present in the daily life of a teacher, who in "have to do" mode ends up experiencing limitations and impotence that he confuses with incapability). It is common to hear teachers say that activities beyond those normally attributed to them are part of their quotidian reality. I hear teachers say things such as, "Sometimes I have to be a psychologist to 
my students, a mother, nurse, social worker..." or even, "I don't know what to do. Every day gets harder..."

This paper makes no claim to solve this problem or indicate ways to solve it. I hope to reflect on the topic from a perspective that can generate a new outlook and a new focus that point to a "poor" pedagogy. To do so, an inversion of the common logic that we employ when thinking about education and with which we view school becomes necessary and from this perspective, some axes become central: 1) to produce a view about the idea of knowledge and learning (2) an awareness of a certain notion of "to teach" and finally (3) starting from a focus on the type of childhood that creates a necessity of "infantilizing" pedagogy, or in other words, we must aim towards a "poor" pedagogy. I will address this through a study carried out with children in the initial stages of their education and literacy learning, starting with a real classroom situation.

\section{Experience and Narration: Prerequisite for Thinking of Educational Practices}

In the reflection that follows, I will follow a path that articulates the notion of understanding and learning, and I will do so starting with narrative discussions of the philosophical tenets of Walter Benjamin. I will begin with a real first grade classroom situation. The scene described below contains one particularity since, more than making reference to a model of failure on the part of the student and the school, the scene demonstrates a notion of learning that escapes our standard idea of academic success:

During a dictation exercise, one child (whom I will call T) writes while the teacher says:

- "Naná."

\footnotetext{
2 "Naná" is a proper name that has no formal English equivalent.
} 
Having heard this, T opens his workbook, which was underneath his desk, finds the "Naná" lesson and copies "Naná." This occurs with various words the teacher dictates and it is for this reason that the student gets every answer right, as he always finds the answer in the corresponding lessons. However, at the end of the dictation, the teacher says:

- Igreja (church).

As expected, T looks for the "igreja" lesson - which does not exist. Yet since "igreja" was one of the words in the "Praça" (plaza) lesson, T quickly copies "Praça." After a few minutes we ask T what he does with the incorrect words and how he corrects them. T explains that when the teacher writes the words on the board, he copies them.

What does $\mathrm{T}$ learn? How does this child learn in the midst of so many questions that we find improbable? What, despite all of the impossibilities posed by teaching, does this exercise offer to the child?

In searching for some indicators of this process, I will refer to the tenets of Walter Benjamin, as already indicated, as well as those of Girgio Aganbem. ${ }^{3}$ I will begin with their ideas on experience and narration. I will attempt to compose something that beckons to the intermittent paths of the authors and in them find questions that indict the problem of experience and narration and how these tenets are connected to some idea about understanding and learning.

To begin, I will indicate that in the philosophical thread of these authors

at present, any discourse about experience must begin from verification of the fact that that - experience - is no longer something achievable. Thus as he was deprived of his biography, modern man is removed from his experience. (AGAMBEN, 2004, p. 7)

Yet what does this mean? What can these philosophers, German and Italian respectively, be telling us?

\footnotetext{
${ }^{3}$ We highlight these ideas because they indicate exactly what we are indicating in this paper.
} 
For these writers (BENJAMIN, 1996; AGAMBEN, 2004) the expropriation of experience is in the project that serves as the basis for modern science, thanks to the models of science and the concepts presented by Western history. Today we understand that experience that is spontaneous is called a case or occurrence and if the experience is explicitly sought after it is called an experiment. Common experience is no longer the behavior of someone who "fumbles" in the dark, as if he were a spinning broomstick, "like someone who at night walks here and there with the hope of finding the right path, when it would be much more useful and prudent to wait for day, turn on a light and shortly thereafter come upon the road" (AGAMBEN, 2004, p. 13). Agamben elaborates:

The true order of experience begins by turning on a light, then catching a glimpse of the road, beginning with an ordered and mature experience and not by an intermittent and biased one, first deducing the axes and then proceeding with new experiences. (AGAMBEN, 2004, p. 14)

Agamben's affirmations lead us to believe that in modernity and above all in and with modern science, we live in a world of distrust and misunderstanding of the discontinuity of time and of things, since we seek a notion of exactness and linearity that must be assured so that we too feel secure. For it is terrible when we get lost in a city, in its streets, for in them we are safe and assured by their maps and references; what is important is the feeling of security and exactness that distance us from labyrinths and in the event that we do enter one, we must be accompanied by, if not Ariadne, at least by the thread that she presents to us so that with it we are able to escape, since often what is challenging is not to end things with our monsters, but to leave our own labyrinths.

In a certain sense we do not need to go back to antiquity to observe these facts. Our concrete reality of the classroom shows us how, guided by the $17^{\text {th }}$ century Didactica Magna by Comenius (1997) and summarized by a speech on discipline and control, we effect a form that pretends to be exact 
and directed, linear and precise about the processes of instruction and learning, suggesting something that more than guaranteeing "success" comforts our fears and defines our control.

The problem appears to accentuate itself when in our culture we need to establish things in a somewhat concrete and stable manner, and we end up having to transform the experience into a scientific certification in the form of an experiment, as it permits us to deduce the sensitive impression with the exactitude of quantitative determinations and be able to foresee future impression - it responds to this loss of certainties that tear and dislocate the experience to what is farthest from man: instruments and numbers. In this way traditional experience loses all of its value.

From these discussions, we have a guarantee that modernity taught us to have, which is if we do not follow the line and foreseen prescriptions in the scientific discourse of psychology and education, we run the risk of producing a legion of people with problems and difficulties, but we also run the risk of not knowing what to say about our lives, that become projects of a series of scenes without meaning in which no plot can be built, where sometimes we become subjects and in others, objects.

Montaigne (1972), in his Essays (perhaps the last modern work on experience), defines his material as a theme without form, which cannot enter into a elaborated production in which it is not possible to found any constant judgment, since "...there is no constant existence, neither in our beings nor in objects, such that it is not possible to establish any certainty about one or the other."

Along this trajectory, what we see is the idea of an experience separated from exact and precise knowledge, which comes back to us so strange that we have forgotten that until the birth of modern science, science and experience each had their own place, and not only that but the subject upon which they each depended was different. The subject of experience was common sense, present in each individual, whereas the subject of 
science and "intelligence," the agent intellect that is separate from experience - in other words, knowledge did not even have a subject in the modern sense of an ego, save that the singular individual was the sub-jectum where the agent intellect, unique and separated effects knowledge. For us it is perhaps easier to say that what is put in place is an idea of a subject of intelligence that interacts with an object of knowledge.

In this separation of experience and science we should see the meaning in the disputes about unicity and the separation and its communication with the subject of the experience. In ancient thought, intelligence and soul are not in effect the same thing, and intellect is not, as we are used to believing, a faculty of the soul - in no way does the intellect belong to the soul except separated, not mixed, not passive, except for the idea that is communicated to effect knowledge (Aristotle). Thus in antiquity the central problem of knowledge was not the relationship between a subject and an object, but rather the relationship between the one and the multiple, thus classic thought did not understand the problem of experience as such, that which for us presents itself as a problem of experience in exchange with a problem of relation, of participation or even as Plato prefers, of differences between the separated intellect and singular individuals, between the one and the multiple, between the intelligible and the sensitive, between the human and the divine.

At this moment a problem presents itself to us, for we have learned during recent years that the understanding/learning process happens or is effected in a perspective of the relationship of a subject with an object; if it is such, how can we think if this relationship presented itself in another form, or in other words, if we could understand that learning is a process of production of meaning that is given through experience. Or even, far from being something that is produced, as modernity proposes, in the intellect, in cognition, which can be something that can be carried out in the quotidian 
practices of human relations of the production of meaning of things and the world.

It is worth remembering that the German Benjamin describes the word experience as Erfahrung - used in Ancient German in the literal sense of go through, cross a region during a trip. Therefore, the true transmission of experience in the source of traditional narration lies in the authority that is not due to a particular wisdom, but rather that circumscribes the poorest man in the hour of his death, or in other words, in the only thing that definitively unites us. To go through, cross, traverse, walk literally means to leave the comfort of home and go out to the world, being that the world is the place of uncertainties, of openings, of ex-positions. Thus, far from being something sure, exact and guaranteed, learning/understanding is something that opens to a variety of possibilities in relation to the processes of the production of the meanings of things and of the world.

One of the problems is that because experience is separate from us and we can only experience it through objects, we already no longer have those very experiences. One example that Benjamin uses to explain this problem is the idea of photography; experience ceases to be something that I carry and becomes something that is outside, and that I have contact with outside of myself and my own sensation.

In trying to find ways and forms to connect ourselves to others, to effect ourselves as beings of experience, and not a subject that relates to an object that appears in the language set of themes, for this becomes the way that connects me to experience, connects me to the other, but also and at the same time that which separates me from the other, or in other words, the notorious mark of my separation, of my distancing. It is through language as well that we attribute meanings, not to what is previously given but to what in the attempt to compose with the other I sew the thread that connects me and for that I share it, the thread that perhaps $\mathrm{T}$ from the opening scene can indicate and present to us. 


\section{Education and School: The Problem of Instruction}

I will define education, broadly speaking, as the total process in which human beings relate to each other, and it is in this relating that they are created and transformed. In this way, education presupposes a space of human relations where words, meanings, affection, bodies and persons position themselves, mark places, define actions and meet. In this sense, we educate ourselves in schools, within our family, in the streets, in bars, in church, in daily life. Education in our modern Western culture ended up institutionalized and gained the contours of the walls of schools and our homes. We can thus see education as a possibility of these compositions, as an effect ${ }^{4}$ of experience.

Nevertheless, our "hunger" for expropriating experience makes us circumscribe this production of meaning in something that we can control, dominate and it is here that I turn to Foucault who in The Order of Discourse is scathing in asking us:

What, in the end, is a system of instruction if not a ritualization of the word, if not a qualification and a fixation of papers with the subjects they discuss, if not a constitution of a doctrinaire group that is at the very least diffuse, if not a distribution and appropriation of discourse with its powers and knowledge? (FOCAULT, 1999, p. 44-45)

Perhaps for some terms used, perhaps for the scathing character with which they are made manifest, perhaps because of what is presented (education), Foucault ends up remarking upon the institutional, almost religious nature of education. It is this aspect that ends up indicating the walls, the fences, the limits of this "practice" of action between people.

In bringing us this perspective, Foucault was marking the place of the ritualizations of speeches that in becoming dogmatized, push us towards ideas of discipline and disciplining. Thinking etymologically about these

\footnotetext{
${ }^{4}$ The original text had the word (e)feito for effect, which represents a play on words of efeito=effect and feito=deed, action, doing.
} 
terms presents us with a variety of possibilities and I will address merely one of them. "Discipline" according to the Etymological Glossary of Teaching Terms by Castello and Márcico (1998) is certainly linked to the Latin verb discere, which means to learn. From the same verb come words such as discipulus - he who learns - the student - the learner - the disciple. In the uses listed first, discipline means teaching, as in education and later came instruction, as in material taught. ${ }^{5}$ These two meanings were retained in Portuguese and gained the following contours: (1) Discipline as power military discipline or I have disciplinary problems with my students. (2) Discipline as knowledge - the disciplines of math, psychology literature, etc.

To speak of education means thus to speak of a field of actions in which "power" and knowledge" interact. Thus to speak of school-based education means to speak of an institution in which this power and this knowledge gain status and a home. In the words of Rancière,

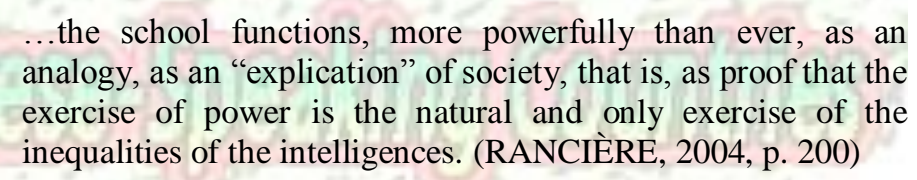

We find ourselves facing a curious situation, that of the relationship between power and knowledge that is established in education. The appropriation of knowledge guarantees the subject the status of power over those who lack knowledge. Relationships that sometimes are guided by "silencing" and "infantilizing" practices, pedagogical practices that mark and define modes and means and a reproductivist learning style of a supposedly single truth, a tutelary education, not an emancipatory one.

The logic of the explanation bears a principle of regression to infinity, according to Rancière in his book The Ignorant Schoolmaster, and

\footnotetext{
${ }^{5}$ Teaching and instruction are the same word in Portuguese $=$ ensino.
} 
adds that the problem is that the explicative mode is always a thinking mode, a logic of the person explaining

\begin{abstract}
the pedagogical myth...divides the world in two. But it must be said that more precisely, it divides intelligence in two. According to it, there is an inferior and a superior intelligence. The first registers perceptions at random, retains, interprets and repeats empirically, in the narrow circle of habits and necessities. It is the intelligence of young children and common men. The latter understands things through reason, proceeds by methods both simple and complex, from part to whole. It is this type of intelligence that allows the schoolmaster to transmit his knowledge, adapting it to the intellectual capabilities of his students and verifying if the student understands what he just finished learning. This is the start to the definition...this is the start to brutalization. (RANCIÈRE, 2004, p. 22)
\end{abstract}

It is important to note that in this logic is inferred another logic, that the relationship between two intelligences is based on the concentration of knowledge in the hands of some - the "superiors" - in detriment to the ignorance of the others - the "inferiors." "Knowledge" guarantees the superior that status of power over the inferior; in this knowledge is guarded supposed secrets and treasures, which only illuminated minds can, within what it possible and indicated, reveal, bring to light, make possible their comprehension.

It is thus that education is processed, it is thus that parents, teachers and educators protect their children, students, learners; it is thus that educational practices are legitimated by scientific discourse such as those of psychology, pedagogy, philosophy, sociology and others, or in other words, it is by "inferiorizing" that we define what allegedly is good for the other.

What is perceptible in this frame is that the numerous initiatives that search for paths for education have found difficulties in breaking (if that is what they intend) with this model and the educational practices continue to bump against their own legs. Thus since finding a path that produces another discourse, or even produces a discourse that could be another discourse, becomes necessary, I will attempt to find space for this possibility and for this I will turn to a discussion on childhood. 


\section{The dead-ends ${ }^{6}$ of infancy}

Looking at the different ways of thinking about education, of the alternative models to the more traditional ones, of the interactionist and constructivist concepts to the deterministic models, all end up drawing closer together, in some form in at least one aspect, in that to educate is in a certain sense to lead the child from the condition of being this being that is not yet what she will one day be. We see with this some indications for anchoring our reflection, since if we can understand that "every" project of transforming children - they who do not possess reason - in series of reason, we can understand that educational practices are organized based on ideas of childhood but that also, by analogy, attempt to end with the childhood of man, or in other words, a ritualization of education would be based on organizing to remove the child from childhood and also childhood from the child, it is thus that we often define practices, actions, curriculum, etc.

Continuing with this viewpoint, all pedagogy is organized based on this assumption and perhaps because of this we had considerable trouble in understanding what $\mathrm{T}$ (the student from the situation presented at the beginning of the text) learns and even in admitting that he learned something. All pedagogy is centered around a discourse that defines, as we have already seen, modes of knowing and learning, as well as modes of teaching. My intuition is to think that an education that did not have this preoccupation with the "pedagogization" of practices would instead not end children's childhood and could permit a return to the infantilization of the adult.

In this sense, an education that desecrates and violates the ritualization indicated would be a practice in which the predominance of the

\footnotetext{
${ }^{6}$ The original word here, des-caminhos, is literally "not paths." Thus instead of the "path" of childhood, we discuss here the "non-paths" of childhood.
} 
construction of reason would no longer be hegemonic and that the foreseeability of docent actions would be based also in an eternal "will-be." Inverting the logic of the Pieta, it would not be the child who lies on the lap of his mother but the reverse; it would be the adult who lies on the lap of the child and with him learns, starting from various possibilities, beyond the field of reason. As Picasso affirmed, in a phrase that became famous for its forcefulness: “...At the age of 12, I painted like an adult... and I needed my entire life to paint like a child."

Thus in the scene described above, some icons appear and gain interesting contours, first because thinking of the possibility that there is a learning there is to indicate almost a transgression, a rupture with something pre-defined, with what comes to be learned, and second because this scene ends up being the door to a passage that perhaps we must go through, since if we assume that there is a portion of meaning there $-\mathrm{T}$ knows in which lessons the dictated words are located and knows how to correct the words on the board - that portion of meaning could be the starting point of seeing not the error, not the impossibility but the path.

In order to reflect a bit more on this topic, I will begin with an analysis of two films that portray the question of childhood in an interesting fashion: The Secret Garden by Agnieska Holland e Central Station by Walter Salles Jr. ${ }^{7}$

The first film, despite having been produced in the 1980s and for portraying children who are possibly from the first half of the century, contains some elements that are interesting for this discussion. The film tells the story of three children of distinct origins who find each other as the

\footnotetext{
${ }^{7}$ We consider it important to emphasize, aside from admitting that there are many films that reflect a productive discussion in regards to childhood and children, we ended up choosing these films with the objective of guiding our reflections, above all because they dialogue with the "thread" that we are stitching in this work, the thread that suggests an inversion of the Western logic of the predominance of reason, for the reason that many possibilities related to subjectivity and their constitution pass on because of reason, but the latter includes the possibility of the constitution of the subject. The relevant explanations are in the discussions that follow in this text.
} 
result of a catastrophe that happens to one of them, Mary Lennox, who is the protagonist of the film. Mary is 10 years old, born in India and the daughter of English parents. At the beginning of the narrative, after an earthquake, she becomes an orphan and goes to live with her uncle in a castle in England's countryside. The second child is a boy named Craven, who is of the same age as Mary and who is also her cousin; he is confined to his room, living isolated and in a perpetual state of sickness. The third child is a peasant boy who accompanies Mary in her discoveries and transformations.

The other characters of the story are the governess Medlock, tough on life, the servants and the children. Her hardness is what produces Craven's sickness and what sustains the sadness of the house; one of the servants, Martha, a plain person who provides moments of light heartedness to balance out the weight of the governess, is who breaks Mary's cultural values by teaching her how to play, dress and be a child; and finally, Mary's uncle, Mr. Craven, a sad man after the death of his wife.

In Holland's film, we see that some motifs are important. Among them we will highlight the key and the girl. We will start with a quotation from Kramer (2000) to build our argument:

The film begins with an earthquake and a fire, foreshadowing sadness and unhappiness: after the death of her mother and father, after the loss of her house, the girl arrives in a place she neither expected nor is special to her. However, as the story develops, the film inverts clichés and reverses the fatalism announced at the beginning. The central object of the plot is the key: the key opens the secret garden that was left locked, just as the children, doors and windows are kept locked, too. But the key that locks can also open...in the film, it is the children that open wide the doors, windows, crevices and holes. (KRAMER, 2000, p. 34)

It is a child who, in attempting to escape from the room the governess locked her into, discovers the key, and in an act of disobedience, of fleeing from the rules, opens the garden and brings back happiness to the castle. 
We will use the key as an icon of reason/lack of reason that locks up the possibilities of finding paths and crevices to solve problems. In the child we see the subversive possibility of breaking with pre-defined logic.

This rupture provoked by the children, their "arts," their "cultivating" of gardens, their magic, fears, uncertainties, insecurities mark a bridge that leads them to break with the hardness of the governess, a hardness that manifests itself in the oppression of bodies, clothes, words and fundamentally of posture, which reached not only the governess but all who lived in the castle, for "...the intricate web of public and private constraints ends up imprisoning each existence in its ever-tightening meshes," (CALVINO, 1995, p. 19).

This disorderly child flees from the rules and indicates the "inhuman" side of what we consider to be the founding of man, and consequently the necessity to amplify the comprehension of childhood in contemporary times, since reason and the full process of its construction hides what is essential in childhood, or even in man himself. In this way, we seek to see the child as a possibility of reconstructing the place of the subject in contemporary times. It is the child, from her non-reason that can see what the adult hides from her rationality and narrates by her discourse with a supposedly univocal word, of full meaning. It is the child, through her imagination, through her make-believe that finds, just as Mary found the garden, in the middle of the "rocks and dry branches," life and the possibilities of making the garden, which in the beginning seemed dead, flourish.

On this path of reflection, we see the classroom, the "supposed" hardness, as an initial indicator in the life of teachers who, without any help, anchor themselves in positions that give them security, give them a guarantee of a place already narrated. We see the students, the children, who break with that hardness with their own narration, by and for them. We also see teachers that look to us seeking help. Perhaps by recognizing the 
hardness of the classroom, of the lives of the children, of their own lives, they can also know the "weight" of levity and their possible avenues for and in education. Like the child, with her modes and forms of learning has much to teach us, the adult/teacher also has much to teach, since

we should remember that this idea of a world constituted of atoms without weight impresses us because we have experience with the weight of things; just as we cannot admire the levity of language if we do not know how to admire equally language endowed with weight. (CALVINO, 1995, p. 27)

Just as in The Secret Garden, Central Station also brings with it possibilities for reflecting on the question of childhood and its relation to education. Walter Salles portrays in an interesting fashion how it is possible to think of one's own life within this complicated game between adult and child. In Central Station, the stories of Dora, an adult, and Josué (Joshua), a child, the plot's central characters, confuse themselves with each other, and in different ways both seem to seek the same objectives, i.e. find their origins and from there reconstruct their own stories. Dora's search happens through memory, of a symbolic reuniting with her father and a brusque change in her life. Josué's search lies in finding through his own experience his real father and thus his lost origin. Gagnebin addresses the

totalization of the object, independent of its chronological insertion. In regards to origin, precisely, it too bears witness to the non-realization of totality. Origin is at the same time evidence of totality and a notorious mark of its absence. (GAGNEBIN, 1994, p. 17)

It appears to be exactly this that Josué and Dora teach us: origin does not mean only the structural law of constitution. Nevertheless, its paths are marked by various happenings. One of them, above all, calls our attention for being directly related to the theme at hand.

In various scenes of the film we see that in attempting to save Josué, Dora ends up being saved by the boy. This is explicit in a scene in which the possibilities of addressing the serious problems both face come from and in the child. After Dora faints, she wakes up in Josué's lap. Here logic is 
inverted as it is the adult that lies in the lap of the child and not the inverse. After this scene, we see the two of them playing. Playing that Josué leaves behind to go out walking through the city and in a few instances finds the solution to the problems they face. The child can look at certain places, such as basements and cellars, much more calmly, without sacrifice and with less effort than adults. Adults, in order to see what is hiding, veiled in the basement need to lower themselves, force themselves.

This set of themes makes us think that in school and in the relationships that occur in it, the possibilities for reflection on the constitution of subjectivity and social relations indicate that in a time like ours marked by multiple outlooks, and by disenchantment, childhood can show the school itself its place, as a place of possibility of what is and no longer of what can be.

Thus, what seems to be disorder, chaos and impossibility can be the true face of things and the possibilities may be in the children themselves, or even, according to Benjamin, in another passage, the child

barely is born and is already a hunter. He hunts the spirits whose vestiges smell in things; between spirits and things years go by, during which his visual field remains free of human beings. What happens next is similar to what happens in dreams: he doesn't recognize anything stable; everything happens to him, the child thinks that everything happens to him, everything hounds him. His years of nomadic life are hours passed in the oneiric forest. From there he drags hurriedly home, to clean it, consolidate it, disinfect it. His drawers need to transform themselves into zoological arsenal, a cryptic or police museum. (BENJAMIN, 1984, p. 79-80)

Thus the "hide-outs," the "desk," the "labyrinth" are images that Benjamin brings to us to say that like Alice, from the classic work of Lewis Carol's Alice in Wonderland, experience ${ }^{8}$ and development ${ }^{9}$ "....reveal the mysterious structure of human desire that does not cease with the obtaining

\footnotetext{
${ }^{8}$ According to Benjamin's definition, experience is not found in something eminently personal but goes beyond this characteristic to encompass something cultural.

${ }^{9}$ Again, Benjamin's definition is employed. For more on the topic, see the references section Bolle (1997).
} 
of its goal, but rather is comprised of inventing and reinventing diversions, images, gestures and words..."(GAGNEBIN, 1994, p. 105).

Benjamin's text (1995) about the desk reveals that the child seeks a certain independence in relation to official instruction, as if he wanted subversive, clandestine learning, that fled from duty and materializes in what is ludic, a clandestinity that also appears in the scene of $\mathrm{T}$ described above. In this space, outside of the rationality of the academic discourse, the child finds his mode of being,

\footnotetext{
over time, in schools the ludic spirit was substituted with duty. With his desk next to the window the child has an affective relation. The desk becomes his favorite nook, a reason for celebration when they meet again when he returns to school. (BOLLE, 1997, p. 10)
}

In this way, we see the possibility of subjectivity in the academic space, for in the counterpoint of the voice with the most weight of the teacher, the protagonist child validates himself with the astuteness of the mimesis to disarm the power of the institution of learning. Representing the "ludic" spirit, the desk [escrivaninha], as a simulacrum of a school desk, is able to dismantle the austere power of it (BOLLE, 1997, p. 10).

Reflecting on this, it is possible to think that the image of man placed in front of that which is presented in the prefix in of the word infancy/childhood sends us back to our original lack of language, word and reason. Although childhood places us at the feet of revelation illuminated by Aganbem of an ineffable experience:

\footnotetext{
Not for having a paradisiacal beginning apart from the words, at the same time without words, without language and however, condition of the possibility of its emergence - that this experience excludes that language can be represented as the totality of the truth. (apud GAGNEBIN, 1997)
}

This would leave us outside of the comfortable condition in which we find ourselves as adults, for reason possesses also its completeness and thus language brings us the mark of childhood, as origin, as incompleteness. 
In this way, childhood reveals to us two faces of our constitution as subjects: one in which we live the illusion of completeness in adult life and the other that sets wide open this explicit incompleteness in childhood itself. The reason that childhood is not "humanity complete and finished is because childhood is, as Lyotard says, in-human that, perhaps indicates to us what is most true in human thought: namely, its incompleteness" (GAGNEBIN, 1997, p. 99). Thus the child reveals to us what we were and what we try to hide at all costs: we are incomplete, unfinished beings, and it is for this also that if the pedagogization of education produced a discourse that leads us to remove childhood from the child and the child from childhood, perhaps thinking of an education that goes back to the roots of pedagogy might make sense and offer new possibilities.

\section{References}

AGAMBEN, Giorgio (2004). Infância e Historia. Buenos Aires: Adriana Hidalgo Editora.

BENJAMIN, Walter (1984). Reflexões: a criança, o brinquedo, a educação. São Paulo: Summus.

BENJAMIN, Walter (1987). Obras escolhidas I: magia e técnica, arte e política. São Paulo: Brasiliense.

BENJAMIN, Walter (1995). Obras escolhidas II: rua de mão única. São Paulo: Brasiliense.

BOLLE, Willi (1997). A ideia de Formação na Modernidade. In: GUIRALDELLI JR., Paulo. (Org.). Infância, Escola e Modernidade. São Paulo: Cortez.

CALVINO, Ítalo (1995). Seis propostas para o próximo milênio. São Paulo: Companhia das Letras.

COMENIUS, Cornelius (1997). A didática magna. São Paulo: Martins Fontes.

CASTELLO, Angel; MARCICO, Claudia (1998). Glosario etimológico de términos usuales em la praxis docente. Buenos Aires. Mimeo. 
FOUCAULT. Michel. (1999). A Ordem do Discurso. São Paulo: Loyola.

GAGNEBIN, Jeanne Marie (1994). História e narração em W. Benjamin. São Paulo: Ed. Perspectiva.

GAGNEBIN, Jeanne Marie (1997). Infância e pensamento. In: GUIRALDELLI JR., Paulo. (Org.). Infância, Escola e Modernidade. São Paulo: Cortez.

KRAMER, Sônia (2000). Infância e Educação Infantil: Reflexões e Lições. LEITE, C. D. P. Educação, Psicologia e Contemporaneidade. Taubaté: Cabral Editora Universitária.

MONTAIGNE, Michel de (1972). Ensaios. Tradução Sérgio Milliet. São Paulo: Editor Victor Civita.

RANCIÈRE, Jacques (2004). O Mestre Ignorante. 2. ed. Belo Horizonte: Autêntica.

\section{Author}

César Donizetti Pereira LEITE

Doctor of Education - School of Education - UNICAMP. Dr. Prof. of the Department of Education - UNESP - Rio Claro.

Phone: Secretary (19) 3526-4245. Office (19) 3526-4271

Work Address: Av. 24 A, 1515 - Bairro Bela Vista - Rio Claro - SP 13506-900

mvhleite@uol.com.br and cesar@rc.unesp.br

Text received 04/2006

Approved for publication 08/2006

\section{WORK CITED:}

LEITE, C. D. P. Narration and Experience: Looking at an Education based on "Poor" Pedagogy - an Analysis based on a Learning-to-Write Situation. Cultivating Literacy in Portuguese-Speaking Countries. Online$\begin{array}{llllll}\text { Only } & \text { Journal. } & 2.5 & \text { (2014): } & 54 & -\end{array}$ <http://www.acoalfaplp.net/en_index.html>. 